University of Warwick institutional repository: http://go.warwick.ac.uk/wrap This paper is made available online in accordance with publisher policies. Please scroll down to view the document itself. Please refer to the repository record for this item and our policy information available from the repository home page for further information.

To see the final version of this paper please visit the publisher's website. Access to the published version may require a subscription.

Author(s): MICHAEL ORTON and KAREN ROWLINGSON

Article Title: A Problem of Riches: Towards a new Social Policy

Research Agenda on the Distribution of Economic Resources

Year of publication: 2007

Link to published version: http://dx.doi.org/

10.1017/S0047279406000377

Publisher statement: None 


\title{
A Problem of Riches: Towards a new Social Policy Research Agenda on the Distribution of Economic Resources
}

\author{
MICHAEL ORTON* and KAREN ROWLINGSON** \\ *Warwick Institute for Employment Research, University of Warwick, Coventry CV4 7AL \\ email: Michael.Orton@warwick.ac.uk \\ ** Department of Social \& Policy Sciences, University of Bath, Bath BA2 7AY \\ email: K.Rowlingson@bath.ac.uk
}

\begin{abstract}
The distribution of economic resources in society is a central concern for social policy. But research in this area has primarily concentrated on the bottom of the economic distribution, namely 'the poor'. In this article, we argue that it is time for social policy to move away from a narrow focus on poverty to consider the broader issue of inequality between different groups in the economic distribution and, by implication, the position of better-off citizens. This raises a number of conceptual challenges due to the current lack of consideration of wealth and inequality at a political, theoretical or empirical level. The article discusses the challenges and concludes by outlining a possible research agenda. However, the underpinning argument is that social policy needs to develop a broader understanding of the economic distribution.
\end{abstract}

\section{Introduction}

The aim of this article is to promote debate about the distribution of economic resources within society and, in particular, whether social policy research should move from a predominant interest in poverty to a greater focus on issues of inequality and wealth. It is close to a hundred years since Tawney (1913: 10) argued that 'what thoughtful rich people call the problem of poverty, thoughtful poor people call with equal justice a problem of riches'. In that time academics and policy makers have devoted a vast amount of time and effort both to the study of poverty, and the development of social policies aimed at poverty reduction. Rowntree (1901), Booth (1903), Townsend (1979), Bradshaw (1993), Gordon et al. (2000), Department for Work and Pensions (2002), Social Exclusion Unit (2004), Lister (2005) and Hills and Stewart (2005) form just the very tip of poverty research. In contrast, there has been very little time and effort devoted to the study of other groups in the economic distribution (notable exceptions being Scott, 1994; Dean, with Melrose, 1999; Byrne, 1999; Rowlingson et al., 1999; Orton, 2006). 
The roots of this imbalance in interest lie, as Scott (1994) argues, in Victorian social policy which did not see wealth as an issue and was structured by a concern to overcome social polarisation through eliminating the problem of poverty. The construction of poverty as a 'social problem' was firmly the product of the nineteenth century, but the same attitudes and ideas still set the terms of debates on poverty and welfare today. Poverty is seen as a social problem in a way that wealth simply is not. As Alcock argues, 'Poverty is the unacceptable face of inequality' (1993: 255).

In this article, we first provide a brief overview of issues of poverty, inequality and wealth under New Labour. We will then examine arguments as to why inequality rather than poverty should be the focus of attention. This leads to a discussion of current knowledge and thinking about the economic distribution, and consideration of the challenges posed by a broader analysis. The final section of the article sets out a possible research agenda. In parts, the article is selfconsciously tentative on the issues raised, in several instances posing questions rather than providing answers. This reflects the lack of research identified and the limitations, such as the absence of a terminology and framework for discussion of inequality, wealth and the economic distribution. However, what underpins the article is the fact that, despite all the efforts referred to above, poverty remains as much an issue in the 21st century as in the 19th. Hence, we argue that a new approach is required.

\section{New Labour: poverty, wealth and inequality}

The imbalance between the very great interest in poverty and the neglect of wealth can be seen under New Labour. A renewal of interest in poverty (compared with its Conservative predecessors) has been a major feature of New Labour policy since 1997. This has been expressed most dramatically in the commitment to abolish child poverty. While there may be debate about the exact achievements being made by New Labour in reducing poverty, it is at least evident that poverty is falling, and certainly addressing poverty is a key issue for the government (examples of recent analyses include Dornan, 2004; Hills, 2004; Hills and Stewart, 2005). But New Labour's treatment of inequality and wealth is more ambiguous.

With regard to inequality, New Labour has certainly displayed concern over some forms of inequality. For example, the gender pay gap has been the subject of considerable policy development under New Labour (for example, see Kingsmill, 2001; Browne, 2004). Racial inequality in employment has similarly been an issue that has received considerable attention, culminating in a commitment that by 2013 ethnic minorities should not face disproportionate barriers to accessing and realising opportunities for achievement in the labour market (Cabinet Office, 2003). New Labour's regional policy can be seen to be in part motivated by a 
concern with economic inequality between geographical areas (Tomaney, 2002). At a more general level is New Labour's concern with diverse but inclusive communities, most recently evidenced by the Home Office (2004) consultation on community cohesion under the theme of 'strength in diversity'.

While New Labour may be concerned with inequality, including economic inequality, on the basis of gender, 'race' and geography, this does not necessarily extend to economic inequality more generally. New Labour's promotion of equality of opportunity over equality of outcomes is well documented (for example, see Hills and Stewart, 2005). Yet what is perhaps more notable is New Labour's lack of attention to economic inequality. In the 1980s, New Right commentators such as Barry (1990) argued that wealth and inequality were necessary for the effective working of a market economy. Conservative governments made similar arguments, Margaret Thatcher (in)famously arguing that the Good Samaritan in the New Testament story was only able to provide help because he had the resources to do so. ${ }^{1}$

New Labour makes no such explicit claims and its approach to inequality is more difficult to discern. As Hills and Stewart (2005) note, amidst New Labour's plethora of poverty-related targets, inequality simply does not appear. Where redistribution has taken place, it has taken place by stealth (Lister, 2005), and is clearly limited to improving the position of those at the bottom of the income distribution relative to those in the middle of the distribution, with those at the top of the distribution 'considered irrelevant' (ibid.: 15). In a television interview prior to the 2001 general election, Blair was asked repeatedly for a view on inequality, to which he responded that 'It's not a burning ambition for me to make sure that David Beckham [an English football player] earns less money.'2 In the 2005 election campaign Blair returned to the issue saying that, 'what I meant ... was not that I don't care about the gap [between high and low incomes], so much as I don't care if there are people who earn a lot of money. They're not my concern. I do care about people who are without opportunity, disadvantaged and poor' (Blair, 2005).

But at the same time an issue such as 'fat cat'3 pay rises has attracted some comment from New Labour. Hewitt (2003) argues that shareholders and trade unions - but in particular pension fund managers - should take (and be given) more responsibility to hold companies to account in terms of regulating salaries and bonuses. She argues that, 'we, the people, own 50 per cent of [the] shares [of publicly quoted companies] ... Big business now belongs to the many, not the few.' However, this has not led to any specific policy development. Similarly, New Labour thinker Peter Mandelson has called for debate about the position of Britain's new 'super wealthy' (Mandelson, 2002), but in reality the focus of policy development on responsibility has been aimed at poor not rich citizens (for example, see Dwyer, 200o). 
After eight years of New Labour government, however, it is perhaps now possible to make clearer judgments about New Labour based on assessment of its policy outcomes as opposed to rhetoric or aspiration. Brewer et al. (2004) argue that under New Labour the UK has experienced an unusual combination of slightly rising income inequality and yet falling relative poverty, which is attributable to two trends: the gap between the very rich, particularly the richest 500,000 individuals, and the rest of the population has got wider since 1997; but, at the same time, many lower-income families have seen their incomes rise faster than the average. However, Goodman and Oldfield (2004) argue that the rising inequality of the 1980s was halted in the 1990s, although it has not been reversed and remains at a 40 year high. These differing conclusions partly reflect methodological approaches: the gap between the very top and bottom incomes has increased, but the gap between those near the top and near the bottom has reduced (see Sefton and Sutherland, 2005). But key trends are apparent. In particular, New Labour has stemmed but not reversed the rising level of income inequality experienced under preceding Conservative governments, and inequality is being driven by changes at the very top of the income distribution not the bottom (ibid.). Thus, the evidence of New Labour's social policy is that, while poverty is falling, there remains gross inequality between those on high and those on low incomes. Inequality is not due to the poor falling further behind but because the rich are getting richer. This stands in contrast both to the post-war period of social democracy with its decreasing poverty and declining inequality, and the 1980 s neo-liberalism, which saw poverty and inequality both increasing. New Labour's combination of falling poverty, increasing riches for the very wealthiest and high levels of inequality, perhaps suggest a 'Third Way' is evident.

Let us now consider, more specifically, the rationale for focusing on inequality rather than just poverty.

\section{Rationale for focusing on inequality}

If the primary concern of social policy is with poverty, and poverty is falling under New Labour, what are the reasons why we might see inequality as a problem? In reviewing the literature, there are a number of arguments that can be made in relation to this question:

- The gap between rich and poor causes social problems

- The combination of private opulence and public squalor causes social problems

- Inequality is a problem because wealth causes poverty

- Inequality is a problem because the process by which some people become rich is unjust

We will consider each of these arguments in turn. 


\section{The gap between rich and poor causes social problems}

An example of the argument that the gap between rich and poor causes social problems can be made in relation to health inequalities. Wilkinson (1996, 2005) has argued that it is inequality rather than absolute poverty that is related to poor health within a society: 'the extent of material inequality is a major determinant of psychosocial welfare in modern societies and its impact on health is but one of the social costs it carries with it' (Wilkinson, 1996: 9). Wilkinson argues that societies that are poor but egalitarian have relatively high levels of good health because of the higher degree of social cohesion within such societies. In egalitarian societies there are strong community bonds between people; public space is social space; there is more involvement in social and voluntary activities outside the home; and there is less anti-social aggressiveness. Higher self-esteem is evident, alongside less stress, depression, anxiety and insecurity. Wilkinson is not arguing that absolute levels of poverty are unimportant in determining health, but that relative levels of income within any society are also important. Daniels et al. (2000) have provided evidence to support Wilkinson's thesis. For example, increases in life expectancy slowed down in the UK in the 1980s just at the time when inequality increased.

However, this argument is controversial (see Jencks, 2002) and the empirical evidence for a correlation between health, well-being and inequality has been questioned. Furthermore, even if a correlation does exist, the causal mechanisms are difficult to pinpoint and the explanation for any causal link also appears weak. There is similar contention in debates about the relationship between inequality and crime (for example, see Neumayer, 2005). Jencks' (2002) own review of evidence about the effects of inequality on a range of socio-economic variables does, however, still point to inequality as a problem. Jencks concludes that: 'the social consequences of economic inequality are sometimes negative, sometimes neutral but seldom - as far as I can discover - positive' (ibid.: 64).

At a more general level, Layard (2005) considered the consequences of economic inequality in relation to his examination of happiness. He argues that the benefit of extra income declines with a person's wealth; if money is transferred from a richer person to a poorer person, the poor person gains more happiness than the rich person loses. Therefore, 'a country will have a higher level of average happiness the more equally its income is distributed' (ibid.: 52). Layard notes that in the 1960 s economists such as James Meade, James Mirrlees and Amartya Sen argued that simply raising taxes could blunt incentives leading to a reduction in total wealth, or the 'size of the cake' as it is described. So the optimum position is argued to be where gains from further redistribution are just outweighed by the losses from the shrinking of the cake. However, empirical research has never examined where this optimum point might be, nor at what level of individual wealth does an increase in income cease to bring additional benefit. 


\section{The combination of private opulence and public squalor causes social problems}

While Wilkinson and others argue that it is the gap between the material resources of the rich and poor which causes social problems, a related but logically distinct argument is that the combination of 'private opulence and public squalor' is a source of social problems (Galbraith, 1977: 195). Galbraith warned of a breakdown in social order in societies where there was an imbalance between the level of spending on public services and the levels of private wealth. Thus, a society may have a fair degree of inequality between rich groups and poor groups but if sufficient resources were allocated to public services then, according to Galbraith, any social problems would be reduced.

But how does the mix of private opulence and public squalor cause problems? Galbraith argues that: 'violence replaces the more sedentary recreation for which there are inadequate facilities or provision ... There is an ample amount of private wealth to be appropriated and not much to fear from the police' (ibid.: 95). As with Wilkinson's argument, the precise explanatory framework underpinning Galbraith's argument is rather weak. And Galbraith provides very little empirical evidence to support his argument. However, at the very least attention is drawn to the need to consider inequality as a potential social problem.

\section{Inequality is a problem because wealth causes poverty}

The preceding two arguments see inequality as a problem because of the effects of a gap between rich and poor, but there is a third argument that takes this perspective one step further, contending that inequality is a problem because wealth actually causes poverty. Tawney (1913: 11) argued that 'the product of industry is distributed in such a way that, whether people fall into distress or not, large groups among them derive a meagre, laborious, and highly precarious living from industries from which smaller groups appear to derive considerable affluence'. It might be thought that such an image of wage slaves and factory owners can be consigned to the hey-day of industrialisation, but a similar point can be made today. As Scott argues: 'the causes of poverty cannot be separated from the causes of wealth: indeed, the one may be a necessary condition of the other' (1994: 18).

To develop the point, Scott further argues (ibid.: 152) that deprivation and privilege are interdependent. They do not simply define the top and bottom of a statistical distribution but are polarised social conditions generated by the confrontation between the public sphere of citizenship and the operation of a market economy. Thus, poverty and wealth are interconnected. There is also a potential link with Bauman's (1998) argument that a divided society will be less secure for everyone. The implication is that poverty and insecurity are not discrete issues but need to be considered within the context of wealth and inequality. This point has been made by Sinfield (2004), in his argument that poverty has to be 
studied as a characteristic of society and not just of those people who are currently living in poverty. Preventive strategies need to pursue the causes 'upstream' and take account of the ways in which resources are distributed throughout society: not only to those in poverty. This entails a closer linking of social with economic and other policies than appears in most anti-poverty debates (ibid.).

There are potentially two different ways of approaching this issue. On the one hand, and this could be seen as risking crude economic reductionism, there is an argument that wealth causes poverty because it simply leaves insufficient resources available for those on low incomes. For example, in the 1980s cuts in welfare benefits combined with tax cuts that particularly favoured high earners, meant there was a very direct redistribution of income from poorer to richer citizens (Oppenheim, 1993). Increasing poverty for some allowed for greater wealth for others. It should also be recognised that these income transfers were based on explicit political choices. A second argument could be seen as relating to the specific position of wealthy citizens. Does increasing inequality mean that the rich opt out of services and/or activities which would link them to poorer citizens, meaning the rich have less concern for other citizens (for example, see Barry, 1998)? This point will be returned to below.

A final approach would be to consider the inter-generational effects of inequality, for example in relation to social mobility. There is general evidence available that social mobility in the UK has declined (Blanden et al., 2005). On a specific issue such as access to higher education, there is again clear evidence of gross inequality, with people living in the most advantaged 20 per cent of areas being five to six times more likely to enter higher education than those living in the least advantaged 20 per cent of areas (Higher Education Funding Council for England, 2005). Research into inheritance (Rowlingson and McKay, 2005) found that people who are already affluent are the most likely to inherit substantial amounts, with the poor least likely to do so. The position of the current generation, with middle-income parents, who are likely to inherit wealth for the first time, means the impact of inheritance on inequality is not entirely clear. However, the position of the already affluent means we could posit the notion of a 'cycle of advantage' as opposed to the cycle of disadvantage originally put forward by Conservative politician Sir Keith Joseph in 1972 and which is marked in New Labour's approach (Deacon, 2002). This leads to our next point, which relates to the processes by which some people become wealthy.

\section{Inequality is a problem because the process by which people become rich is unjust}

The arguments so far have considered inequality as a problem because of its effects. A different approach is to consider whether the processes by which some members of society become rich are a problem. If a society were completely meritocratic 
and all members of that society started life on an even footing, then it could be argued that any resulting inequality would be socially just. The underlying philosophical framework here relates to Nozick (1974), who argued that Kant's principle of treating humans as ends entitled individuals to be rewarded for their natural talents (see Callinicos, 2000). This argument for meritocracy has appealed to a wide range of politicians. For example, Crosland (1956) believed that inequality of earnings was acceptable because people deserved reward if they had superior talent or if it acted as an incentive to do work which was risky and/or burdensome in terms of responsibility. Tony Blair and Gordon Brown are both prominent supporters of equality of opportunity rather than equality of outcome.

But the extent to which Britain is a meritocracy has been repeatedly questioned. Despite Saunders' (1996) attempts to argue that Britain is a meritocratic society, the weight of evidence and academic argument lies against him (Breen and Goldthorpe, 1999). Two studies by the Institute for Fiscal Studies (Dearden et al., 1996; Johnson and Reed, 1996) reached the conclusion that the best way to become rich is to choose your parents wisely: 'the economic standing of parents is an extremely important determinant of where their children end up in the income distribution'. Thus, 'brute luck' (in terms of whether a child is born to a rich or poor family) plays a major role in determining life chances.

But, even if a society could be engineered such that there was 'deep' or total equality of opportunity, would any resulting level of inequality be just? Rawls (1972) argued that it was justifiable for people's natural talents to be rewarded (and therefore create some inequality) if the consequence of this was to produce more wealth overall, which would then benefit the poorest. There is very little evidence, however, that wealth at the top 'trickles down' to benefit the poorest. The 1980s saw the accumulation of staggering amounts of wealth in the hands of a minority of US and UK citizens, but the decade also saw an increase in poverty, hardship and 'public squalor'. There is no evidence that those at the bottom benefited from the economic boom of the time.

The philosophical debate on inequality has now turned away from equality of opportunity and equality of outcome towards equality of capabilities (Sen, 1992), equality of access to advantage (Cohen, 1993) and equality of access to well-being (Callinicos, 2000). But various issues remain in relation to the previous debates. How do we secure a 'deep' level of equality of opportunity, and should there nevertheless be limits applied to any resulting inequality? For example, Crosland (1956: 101) was still in favour of enough equality of income to 'minimise social resentment, to secure justice between individuals and to equalise opportunities'.

There are, therefore, clear arguments as to why inequality and wealth, not merely poverty, should be the concern of social policy. We shall consider below the challenges posed by a broader analysis of the economic distribution. Before doing so, however, we will first examine current knowledge and thinking on this issue. 


\section{Current knowledge and thinking about the economic distribution}

In this section we will consider contemporary knowledge and thinking about the nature of the distribution of economic resources. The starting point is current trends in inequality.

\section{Trends in inequality}

While there is considerable debate about the exact extent of poverty and inequality in the UK, it is certainly clear that the gap between rich and poor is hugely greater than during the post-1945 period. Scott (1994) and Dean, with Melrose (1999) provide detailed analyses of historical trends in inequality, but for our purposes here it is necessary simply to highlight the extent of inequality. From the early 1960 s to the early 1990s, the share of the richest 10 per cent of the population increased from 21 per cent of income to 26 per cent (Goodman and Webb, 1994). The incomes of the richest decile grew at twice the speed of the poorest decile (Goodman et al., 1997). Figures for gross annual income before housing costs show that, in 2000/01, the top 20 per cent of the population had an average gross annual income of $\mathfrak{E}_{56,850}$ per annum, seven times more than the income of the bottom 20 per cent. ${ }^{4}$ The direct tax system goes some way to reducing this level of inequality but only to a ratio of 6 to 1 (rather than 7 to 1 ).

Most of the research on material resources has concentrated on income, but there is an even higher degree of inequality if we look at assets. As Paxton and Taylor (2002) have argued, the last few decades have seen exuberant wealth creation. Between 1988 and 1999, the top 1 per cent of the population increased its share of personal wealth from 17 per cent to 23 per cent. The top 2.4 million households owned $\mathfrak{E}_{1,300}$ billion of wealth in 1999 compared with the paltry $\mathfrak{E}_{150}$ million owned by the bottom 12 million households. Rowlingson et al. (1999) found that the top 10 per cent of the population owned half of all assets in the mid 199os. The top 20 per cent owned about 70 per cent. In contrast, two thirds of UK families have no savings at all (Regan, 2001).

\section{Previous research into the economic distribution}

Relative to the very extensive literature on poverty, research on inequality and wealth has hardly advanced since pioneering studies of the early twentieth century, for example by Chiozza-Money (Scott, 1994). Scott has made one of the few contributions to this debate through a discussion of privilege. Scott argues that privilege occurs when people have things that most people cannot afford. Deprivation, on the other hand, is to be forced to lack things that most other people have. Scott points out that the terms privilege and deprivation come from the same etymological roots (the Latin word privatus). He also sees a common root in relation to social exclusion as he sees both rich and poor as excluded from mainstream society, if in rather different ways. For example: 'those who are privileged - the wealthy - are those whose location in the economic system 
means that the resources available to them are such that they are able to establish 'private' lifestyles and modes of consumption from which others are excluded' (Scott, 1994: 152). Scott goes on to argue that: 'privilege, understood in relative terms, is a condition in which people are able to enjoy advantaged powers and opportunities, life chances that are superior to those that are normal in their society'. Giddens (1998) similarly compares the forced exclusion at the bottom of society with the voluntary exclusion at the top, where people withdraw from public institutions, and more recently has argued that high incomes should be a policy concern if they set the rich apart from the rest of society (Giddens, 2004) along with calls for a 'new egalitarianism' (Giddens and Diamond, 2005).

Dean and Melrose (1999) carried out qualitative research and their respondents identified two groups towards the top of the economic distribution: a group who lived in 'comfort' and a group that were able to have 'fun' without any economic worries. This latter group were seen by respondents as being rich and living in a state of 'privilege'. Respondents reported that people in this last category consisted of celebrities, chief executive 'fat cats', people who had inherited wealth and self-made millionaires. This provides an interesting start to any discussion on socio-economic divisions, but Dean and Melrose do not provide any suggestions as to how to draw lines between these groups. For example, at what level of income or assets do people move from a state of 'worry' to a state of 'comfort'?

\section{Challenges posed by a broader analysis of the economic distribution}

From the outset, there are a number of challenges posed by re-focusing attention on to the broader economic distribution. This section of the paper discusses three challenges. First, we look at appropriate terminology. Second, references have been made above to assets as opposed to income. In addition to the focus of social policy and political debate on poverty rather than wealth and inequality, there is also an imbalance in the consideration given to income rather than assets. Quite simply, the vast majority of poor people have no assets, so a focus on poverty means there has been little point in studying assets as an economic resource. But the converse also applies: if we are interested in inequality more broadly, then we should consider assets alongside income because those at the top of the economic distribution hold considerable levels of personal wealth. In this section, we will examine how to combine income and assets in any analysis. Third, we will consider how to define the economic distribution in a meaningful way.

\section{Terminology}

'Poverty' may be a highly contested term but there is at least a framework for debate in terms of definition (for example, absolute and relative conceptions of poverty) and measurement (for a recent discussion see Lister, 2005). Debates 
about poverty can also often involve the use of other terms such as 'hardship', 'deprivation', 'low income', 'disadvantage', 'social exclusion' and so on. Once again there is a literature on each of these and their definition (also see Lister, 2005), but there is much less of an agreed framework for talking about the economic distribution more generally. For example, Scott (1994) talks about 'privilege' and uses the term 'wealthy' to describe people in a state of privilege. Another term often used in this field is 'riches'.

However, such terminology lacks clarity and instead raises a series of questions. For example, are rich people those with high incomes or high levels of assets or both? How high do assets and income have to be for someone to be considered 'rich' or 'wealthy' or 'affluent' or 'privileged'? What is the difference, if any, between the rich and the wealthy? Are these terms absolute or relative? In addition, how do we talk about those that fall between the rich and the poor? The term 'Middle England' has become a very powerful one in political discourse, but are these people really in the middle of the economic distribution? And which middle are we talking about: the mean or the median? (for a discussion see Wakefield, 2003).

There is again a need to consider the question of assets. Assets are often referred to as 'wealth' and yet the term 'wealthy' might be used to refer to those with very high incomes but low levels of assets. So the term 'wealth' can itself be misleading. The term 'assets' is, perhaps, more neutral, referring to a stock of economic resources such as housing assets, financial savings, pension assets, land, valuables and so on. The key point, however, is that we lack a framework for discussing the broader economic distribution.

\section{Combining income and assets}

As noted above there is an imbalance, within social policy, as to the consideration given to income rather than assets, but there are a number of reasons why ownership of assets is interesting. Ownership of assets is about more than a stored income. Sherraden (1991) has argued that assets can enable people to look forward to the future with confidence and security. They allow people to take risks and make long-term plans. So, 'income may feed stomachs, but assets feed minds' (Sherraden, 1991, cited in Kelly and Le Grand, 2001: 50). Empirical studies in this field have come up with contradictory findings about any 'asset effect' (Bynner and Despotidou, 2001; McKay and Kempson, 2003), but assets may help people cope with social problems such as unemployment better than those with no assets (for example, see Marsh, 1994). Assets also give people certain choices other groups simply do not have. For example, it gives the option of drawing on savings and the option of releasing equity from housing (either by using equity release schemes, trading down or selling a home and moving into rented accommodation).

While on average levels of income and assets are highly correlated among individuals, there are some groups who are 'income poor, asset rich' (particularly 
some pensioners) (Rowlingson et al., 1999). Even if we were only interested in poverty (defined by income), we might still want to look at assets among some groups.

The issue of how to include assets in defining the income distribution at the level of the individual has been raised in recent research by one of the authors. ${ }^{5}$ Let us consider three examples from the research.

Example 1. The interview was with a man who had been unemployed for six months. His wife worked part-time earning approximately $\mathfrak{E}_{15}, 000$ per annum. The couple had three children of school age. The family would appear to be on a low income. However, the man's earnings had previously been between $\mathfrak{E}_{50,000}$ and $\mathfrak{E} 80$, ooo per annum. The couple had used savings of over $\mathfrak{E}_{30}$, ooo to live off during the six months of the man's unemployment. With housing equity of

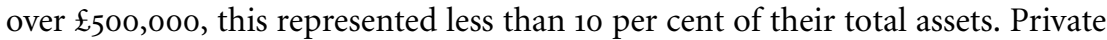
education had still been affordable for the couple's children.

Example 2. The interview was with a woman. Her and her husband's combined income was between $\mathfrak{E} 50$, 000 and $\mathfrak{E} 80$, 000, more than twice the national average. The couple had housing equity of $\mathfrak{E}_{320}$, ooo and savings of $\mathfrak{E}_{15}, 000$. The couple appeared financially very comfortable. However, the couple were self-employed and had made no pension provision whatsoever. Both had turned 50 and their sole retirement planning consisted of selling their house at some future date. Sustaining their high income into retirement appeared unlikely.

Example 3. The interview was with a couple with an income very close to the national average. However, an inheritance provided the couple with capital of $\mathfrak{E} 120$,ooo. In addition, the couple's home had been purchased when the husband was in a higher paid job and now provided housing equity of $\mathfrak{E} 550,000-\mathfrak{E} 650,000$. Thus, the couple may have had an average income but their total financial resources were in the region of three quarters of a million pounds.

What these three examples illustrate is the importance of considering assets as well as income in analyses of the economic distribution. It raises questions as to whether income is predictive of assets, how assets can be used up very quickly in old age, and what data sources can be drawn on. For example, the Family Resources Survey provides rich detail regarding income, but does not record full details of savings and capital above $\mathfrak{E} 20,000$. We do not claim to have the answer to the question of how to combine income and assets, but it is a question that deserves more attention and research.

\section{Defining the economic distribution}

A further challenge posed by taking a broader approach than simply focusing on poverty and income is the issue of how to define the economic distribution. 
Scott (1994) and Giddens (1998) both consider those at the 'top' of the distribution to be a particularly privileged group and they define them as people who have the ability to exclude themselves from society. An exclusive lifestyle could be identified using a range of indicators, such as: ability to afford luxuries, ability to afford private welfare, ability to afford at least one substantial and secure residence, absence of arrears and lack of money worries.

In theory, it would be possible to consider how much an 'exclusive' lifestyle would cost and then work out how much income and/or assets would be needed to buy luxury goods and/or an 'exclusive' lifestyle. For example, we could calculate how much private health care and private education costs, how much it costs to have a substantial and secure residence, how much it costs to afford adequate private pension payments, how much it costs to own luxuries and so on. This approach would mirror the 'basket of necessities' measure of poverty used by Rowntree (1901), Bradshaw (1993), Parker (1998) and Bernstein et al. (2000). No-one so far has come up with a 'basket of luxuries' measurement for the top of the economic distribution but divorce cases involving affluent couples have sometimes involved costing a high standard of living. In one case, in 1998, the former wife of Lord Spencer tried to make the case that it would be very difficult to make ends meet and raise her children with the $\mathfrak{E} 1.8$ million settlement that she had been awarded. ${ }^{6}$

Another possible approach to measuring the top of the economic distribution is the social indicator approach. People could be considered 'rich' or 'privileged' if they possess certain luxuries. The social indicator approach was first developed in relation to poverty by Townsend (1979) and then modified by Mack and Lansley (1985), Gordon and Pantazis (1997) and Gordon et al. (2000). This approach could be extended to the top of the distribution. For example, if people possess a number of 'luxuries' they could be defined as rich. These luxuries could be defined by an 'expert' (Townsend's approach) or by the general public (Mack and Lansley's consensual approach). Also, if someone lacks a luxury item, it would be possible to ask them whether this is because they do not want it or they cannot afford it. Those that can afford a luxury could be included in the measure, even if they choose not to have it.

At a more general level, British Social Attitudes surveys ask respondents how much they think people in certain occupations actually earn, and should earn. For example, in 1999 it was found that respondents thought a chairman of a corporation should be paid six times more than an unskilled worker (Hills, 2004). Further research could explore this in more detail: for example, what public attitudes are towards a notion of a maximum income and at what level any such 'line' should be drawn.

In the absence of studies which have taken these approaches to the economic distribution, we could use a relative measure. The government currently uses a relative measure to analyse poverty: people are considered poor if their income 
is below 60 per cent of median income. A similar approach could be taken to measure the top of the distribution: for example, we could choose our threshold as the top 10 per cent or 20 per cent of those in the income distribution. Goodman et al. (1997) found that the top 10 per cent had a quarter of all income and the top 30 per cent had half of all income. Scott (1994) argues that the top 1 per cent of the economic distribution is often taken as a proxy for measuring wealth. Again, this could lead to the development of a 'wealth line' to complement the current 'poverty line'.

At this stage, it is also necessary to reflect that other dimensions such as gender and 'race' need to be included in a broader analysis of the economic distribution. For example, Goodman et al. (1997) found that men were more likely than women to be in high-income groups. High income was most common among working-age people without children. But it was also found that there was a great deal of inequality within different family types. For example, some pensioners were quite affluent in income terms, whereas some were very poor. The picture of inequality was quite heavily dependent on the precise way it was measured, with pensioners, for example, no longer predominating among the poor on income measures, but still dominating if expenditure measures were used. With regard to 'race', Modood et al. (1997) have pointed to the divergence in the economic circumstances of the main minority ethnic groups.

Having identified challenges posed by a broader analysis of the economic distribution, the next section will consider a possible research agenda.

\section{Towards a new research agenda}

The above discussion highlights how the neglect of issues of inequality and assets constrains our understanding of the broader economic distribution. This suggests the need for a research agenda. We would posit the following possible starting points.

\section{Conceptualising the economic distribution}

Public understanding and attitudes to inequality and the means by which people become rich or poor is critical in providing a framework for analysis. There does appear to be widespread concern about inequality along with some support for redistribution among the public at large. Hills (2001) shows that in 2000 over 80 per cent of the public said that the gap between rich and poor was too great, and 39 per cent believed that the government should redistribute income to the less well off (though 33 per cent disagreed). Another 38 per cent agreed that the government should spend more money on welfare benefits for the poor (though 30 per cent disagreed). So public support is divided, but a substantial majority of the population consider inequality a problem, and a significant proportion support redistribution. There is also support for modest tax rises if the revenue is spent on education and health, but there is less public support for expenditure 
on social security (Taylor-Gooby and Hastie, 2002). More detailed knowledge about the divisions in social attitudes, and greater understanding of how people conceptualise and define the economic distribution, would help us greatly in getting beyond the generalities of British Social Attitudes surveys.

\section{The nature and effects of inequality}

Much more research is needed into the causes, nature and consequences of inequality. Jencks (2002: 65) carried out a review of research on inequality and concluded that there is far too little empirical research on this subject: it is remarkable how little effort rich societies have made to assemble the kinds of evidence they would need to assess the costs and benefits of limiting inequality'. While Jackson and Segal (2004) have recently set out an historical perspective as to why inequality matters, we simply do not have a sufficient empirical base from which to promote an informed debate about the effects of inequality on contemporary societies.

\section{Combining income and assets}

A key point made in this article relates to the role of assets. More information is needed about this important component of economic resources, which is far more unequally shared than income. There is also an important point to be made here in relation to poverty research. We have seen that some groups who are poor on income grounds (such as pensioners) may nevertheless have assets which put them in a different position from other poor groups. More research needs to take place into income-poor/asset-rich groups. Current research, such as that by Rowlingson et al. (1999), takes a rather arbitrary approach looking at those above the median on income and assets and calling them 'income rich, asset rich'. But income and assets need to be combined in a more meaningful way so as to consider the distribution of economic assets overall. Thus, a more sophisticated approach to the consideration of assets within analyses of the economic distribution is required.

\section{Policies relating to inequality and assets}

A focus on inequality also requires moving beyond social policy analysts' traditional concern with poverty and welfare. Taxation is one of the main ways in which governments affect the well-being of citizens, but studies of welfare pay remarkably little attention to its impact (Sinfield, 2003). In addition, contemporary debates have become very narrowly focused on social welfare (Dwyer, 2000), ignoring broader definitions first put forward by Titmuss (1958) that include occupational and fiscal welfare. Studying inequality means moving beyond a concern with social welfare to a much broader conception of 'well-being' and recognising how wealthy citizens benefit from fiscal welfare.

At a policy level, there is some evidence of inequality beginning to be seen as an issue. For example, the Fabian Society has considered the issue of inheritance 
tax, which many of the very rich manage to avoid or evade (Patrick and Jacobs, 2003). They call for a new Capital Receipts Tax on any lifetime gifts or inheritance. This new Capital Receipts Tax would take into account the financial circumstances of the recipient so that poorer recipients would pay less tax than the better off. The Fabian Society argues that any extra revenue from this new tax should be directed towards asset-based welfare schemes to increase the levels of assets of poorer groups. Another example is an argument by the Institute for Public Policy Research that home-owners in expensive properties should pay higher rates of local tax to help fund a building programme for social housing (Holmes, 2003). Such ideas perhaps indicate a rather basic redistributionalist view that if poverty is to be reduced, the rich need to pay more tax, but at the very least they promote debate beyond a concern with social welfare to include fiscal, and potentially occupational, welfare.

\section{'Looking up' to the rich}

As Byrne (1999) argues, social science tends to have its eyes down on the poor rather than looking up at the rich and the 'excluding few'. Moving beyond a concern solely with poverty and poor citizens also requires a focus on wealthy citizens themselves. Dean and Melrose (1999) found that newspapers give far greater coverage to issues of wealth than poverty, but the nature of public interest in the wealthy can be described as a 'prurient fascination'. But why should issues such as the 'idle rich' not be the subject of social scientific investigation? This also returns us to issues of meritocracy and the means by which people become rich. The contribution made to society by the rich, the responsibilities of wealthy citizens and the hidden benefits provided by occupational and fiscal welfare, all merit further research.

\section{Conclusion}

In seeking to promote debate about a broader understanding of the economic distribution, we have raised questions rather than necessarily provided answers, and in parts our discussion (reflecting limitations in data and terminology) has been tentative in the issues covered. However, we have outlined a number of possible reasons why inequality might be considered a social problem and called for further thinking and debate in this area. We have reviewed current knowledge and thinking about the economic distribution and highlighted challenges faced by a broader analysis of the economic distribution. In particular, our terminology around 'wealth', 'riches' and 'privilege' needs further development, our methods of combining income and assets need greater consideration and we need to collect more empirical data on assets in order to further our analysis of this subject. Finally, we set out a possible research agenda covering: conceptualisation of the economic distribution, the nature and effects of inequality, methods of 
combining income and assets and policies relating to inequality and assets. There is much to do but the first step is to acknowledge the need for further thinking and debate in this field. Tony Blair may not care about people who earn a lot of money, but it is high time social policy analysts put riches on the agenda.

\section{Acknowledgment}

Our thanks to the two anonymous referees for their very helpful comments.

\section{Notes}

1 Source: www.margaretthatcher.org/search/displaydocument.asp?docid=104210\&doctype $=$ 1.

2 A note of the interview can be found at: http://news.bbc.co.uk/1/hi/events/newsnight/ 1372220.stm.

3 The term 'fat cat' is regularly used in UK newspapers to describe those on very high salaries, particularly in relation to such people receiving pay increases or other financial benefits. A recent example was Sir Peter Davis, chairman of the grocery retailer Sainsbury's, whose annual salary of $\mathfrak{E} 850$, oo was supplemented by being given shares in the company worth $\mathfrak{E} 2.4$ million, despite the company's poor performance (for example see The Observer, 23 May 2004).

4 Source: http://www.nationalstatistics.gov.uk/StatBase/Expodata/Spreadsheets/D6256.xls.

5 The research project was entitled 'Local taxation, wealth and citizenship' and was funded by the UK Social and Economic Research Council under award reference RES-000-22-0597 (also see Orton, 2006).

6 Source: http://bbc.co.uk/news/1/hi/uk/187808.stm.

\section{References}

Alcock, P. (1993), Understanding Poverty, Basingstoke: Macmillan Press.

Barry, B. (1998), Social Exclusion, Social Isolation and the Distribution of Income, CASEpaper 12, Centre for Analysis of Social Exclusion.

Barry, N. (1990), 'Markets, citizenship and the welfare state: some critical reflections', in R. Plant and N. Barry (eds), Citizenship and Rights in Thatcher's Britain: Two Views, London: IEA Health and Welfare Unit.

Bauman, Z. (1998), Work, Consumerism and the New Poor, Buckingham: Open University Press.

Bernstein, J., Brocht, C. and Spade-Aguilar, M. (2000), How Much is Enough? Basic Family Budgets for Working Families, Washington, DC: Economic Policy Institute.

Blair, T. (2005), 'We've got to carry this on', Progress, March (available at www.progressives. org.uk/report/default.asp?action=magazine\&articleid $=867$ ).

Blanden, J., Gregg, P. and Machin, S. (2005), Intergenerational Mobility in Europe and North America, London: Centre for Economic Performance, London School of Economics.

Booth, C. (1903), Life and Labour of the People of London (17 vols), London: Macmillan.

Bradshaw J. (ed.) (1993), Budget Standards for the United Kingdom, Aldershot: Avebury.

Breen, R. and Goldthorpe, J. (1999), 'Class inequality and meritocracy: a critique of Saunders and an alternative analysis', British Journal of Sociology, 50: 1, 1-27.

Brewer, M., Goodman, A., Myck, M., Shaw, J. and Shephard, A. (2004), Poverty and Inequality in Britain: 2004, London: Institute for Fiscal Studies.

Browne, J. (2004), 'Resolving gender pay inequality? Rationales, enforcement and policy', Journal of Social Policy, 33: 4, 553-571.

Bynner, J. and Despotidou, S. (2001), Effect of Assets on Life Chances, London: Institute of Education. 
Byrne, D. (1999), Social Exclusion, Buckingham: Open University Press.

Cabinet Office (2003), Ethnic Minorities and the Labour Market: Final Report, London: Cabinet Office.

Callinicos, A. (2000), Equality, Cambridge: Polity Press.

Cohen, G. (1993), 'Equality of what? On welfare, goods and capabilities', in M. Nussbaum and A. Sen (eds), The Quality of Life, Oxford: Oxford University Press.

Crosland, A. (1956), The Future of Socialism, London: Cape.

Daniels, N., Kennedy, B. and Kawachi, I. (2000), Is Inequality Bad for our Health?, Boston: Beacon Press.

Dean, H. with Melrose, M. (1999), Poverty, Riches and Social Citizenship, Basingstoke: Macmillan.

Deacon, A. (2002), 'Echoes of Sir Keith? New Labour and the cycle of disadvantage', Benefits, 10: $3,179-184$.

Dearden, L., Machin, S. and Reed, H. (1996), Intergenerational Mobility in Britain, London: IFS.

Department for Work and Pensions (2002), Measuring Child Poverty: A Consultation Document, London: Department for Work and Pensions.

Dornan, P. (2004), 'Ending child poverty by 2020: the first five years', in P. Dornan (ed.), Ending Child Poverty by 2020: The First Five Years, London: CPAG.

Dwyer, P. (2000), Welfare Rights and Responsibilities, Bristol: Policy Press.

Galbraith, J. (1977), The Affluent Society (2nd Edition), London: Hamish Hamilton.

Giddens, A. (1998), The Third Way, Cambridge: Cambridge University Press.

Giddens, A. (2004), 'We can and should take action if the earnings of the rich set them apart from society', New Statesman and Society, 27 September.

Giddens, A. and Diamond, P. (eds) (2005), The New Egalitarianism, Cambridge: Polity Press.

Goodman, A. and Oldfield, Z. (2004), Permanent Differences? Income and Expenditure Inequality in the 1990 s and 200os, London: IFS.

Goodman, A. and Webb, S. (1994), For Richer and Poorer: The Changing Distribution of Income in the United Kingdom 1961-1991, London: IFS.

Goodman, A., Johnson, P. and Webb, S. (1997), Inequality in the UK, Oxford: Oxford University Press.

Gordon D. and Pantazis C. (eds) (1997), Breadline Britain in the 1990s, Aldershot: Ashgate.

Gordon, D., Adelman, L., Ashworth, K., Bradshaw, J., Levitas, R., Middleton, S., Pantazis, C., Patsios, D., Payne, S., Townsend, P. and Williams, J. (2000), Poverty and Social Exclusion in Britain, York: Joseph Rowntree Foundation.

Hewitt, P. (2003), 'Why people power is good for business', New Statesman, 3 November, 34-35.

Higher Education Funding Council for England (2005), Young Particpation in Higher Education, Bristol: Higher Education Funding Council for England.

Hills, J. (2001), 'Poverty and social security: what rights? Whose responsibilities?', in A. Park, J. Curtice, K. Thomson, L. Jarvis and C. Bromley. (eds), British Social Attitudes, the 18th Report, London: Sage.

Hills, J. (2004), Inequality and the State, Oxford: Oxford University Press.

Hills, J. and Stewart, K. (eds) (2005), A More Equal Society? New Labour, Poverty, Inequality and Exclusion, Bristol: Policy Press.

Holmes, C. (2003), Housing, Equality and Choice, London: IPPR.

Home Office (2004), Strength in Diversity: Towards a Community Cohesion Strategy and Race Equality Strategy, London: Home Office.

Jackson, B. and Segal, P. (2004), Why Inequality Matters, London: Catalyst.

Jencks, C. (2002), 'Does inequality matter?', Daedalus, Winter, 49-65.

Johnson, P. and Reed, H. (1996), Two Nations? The Inheritance of Poverty and Affluence, London: IFS.

Kelly, G. and Le Grand, J. (2001), 'Assets for the people', Prospect, 69: December, 50-53.

Kingsmill, D. (2001), The Kingsmill Review of Women's Pay and Employment, London: Cabinet Office, Department of Trade and Industry, and Department for Education and Skills.

Layard, R. (2005), Happiness: Lessons from a New Science, London: Allen Lane. 
Lister, R. (2005), Poverty, Cambridge: Polity Press.

Mack, J. and Lansley, S. (1985), Poor Britain, London: Allen \& Unwin.

McKay, S. and Kempson, E. (2003), Savings and Life Events, DWP Research Report 194, Leeds: Corporate Document Services.

Mandelson, P. (2002), 'Third way is the only way', The Guardian, 10 January.

Marsh, A. (1994), 'The benefit fault line', in M. White. (ed.), Unemployment and Public Policy in a Changing Labour Market, London: Policy Studies Institute.

Modood, T., Berthoud, R., Lakey, R., Nazroo, J., Smith, P., Virdee, S. and Beishon, S. (1997), Ethnic Minorities in Britain: Diversity and Disadvantage, London: Policy Studies Institute.

Nagel, T. (1991), Equality and Partiality, Oxford: Oxford University Press.

Neumayer, E. (2005), 'Inequality and violent crime: evidence from data on robbery and violent theft', Journal of Peace Research, 42: 1, 101-112.

Nozick, R. (1974), Anarchy, State and Utopia, Oxford: Oxford University Press.

Oppenheim, C. (1993), Poverty: The Facts, London: CPAG.

Orton, M. (2006), 'Wealth, citizenship and responsibility: the views of better off citizens in the UK', Citizenship Studies, 10: 2, 251-265.

Parker, H. (ed.) (1998), Low Cost but Acceptable: A Minimum Income Standard for the UK, London: Family Budget Unit.

Patrick, R. and Jacobs, M. (2003), Wealth's Fair Measure: The Reform of Inheritance Tax, London: Fabian Society.

Paxton, W. and Taylor, M. (2002), 'Bridging the wealth gap', New Statesman, 12 July.

Rawls, J. (1972), Theory of Justice, Oxford: Oxford University Press.

Regan, S. (2001), Assets and Progressive Welfare, London: IPPR.

Rowlingson, K. and McKay, S. (2005), Attitudes to Inheritance in Britain, Bristol: Policy Press.

Rowlingson, K., Whyley, C. and Warren, T. (1999), Wealth in Britain: A Lifecycle Perspective, London: Policy Studies Institute.

Rowntree, S. (1901), Poverty: A Study of Town Life, London: Macmillan.

Saunders, P. (1996), Unequal but Fair? A Study of Class Barriers in Britain, London: IEA.

Scott, J. (1994), Poverty and Wealth: Citizenship, Deprivation and Privilege, Harlow: Longman.

Sefton, T. and Sutherland, H. (2005), 'Poverty and inequality under New Labour', in J. Hills and K. Stewart. (eds), A More Equal Society? New Labour, Poverty, Inequality and Exclusion, Bristol: Policy Press.

Sen, A. (1992), Inequality Re-examined, Oxford: Oxford University Press.

Sherraden, M. (1991), Assets and the Poor: A New American Welfare Policy, New York: Armonk.

Sinfield, A. (2003), 'Changing tax welfare', paper presented at the ESPAnet Annual Conference, 'Changing European Societies - The Role For Social Policy', 13-15 November, Copenhagen.

Sinfield, A. (2004), 'Preventing poverty in market societies', paper presented at the ESPAnet Annual Conference 'European Social Policy: Meeting the Needs of a New Europe', 9-11 September, Oxford.

Social Exclusion Unit (2004), Breaking the Cycle: Taking Stock of Progress and Priorities for the Future, London: Office of the Deputy Prime Minister.

Tawney, R. (1913), 'Poverty as an industrial problem', inaugural lecture, reproduced in Memoranda on the Problems of Poverty, London: William Morris Press.

Taylor-Gooby, P. and Hastie, C. (2002), 'Support for state spending: has New Labour got it right?', in A. Park, J. Curtice, K. Thompson, L. Jarvis and C. Bromley. (eds), British Social Attitudes: 19th Report, London: Sage.

Titmuss, R. (1958), Essays on the Welfare State, London: Allen \& Unwin.

Tomaney, J. (2002), 'New Labour and the evolution of regionalism in England', in J. Tomaney and J. Mawson (eds), England: The State of the Regions, Bristol: Policy Press.

Townsend, P. (1979), Poverty in the United Kingdom, Penguin: Harmondsworth.

Wakefield, M. (2003), Is Middle Britain Middle-Income Britain?, Briefing Note, No. 38, Institute for Fiscal Studies.

Wilkinson, R. (1996), Unhealthy Societies: The Afflictions of Inequality, London: Routledge.

Wilkinson, R. (2005), The Impact of Inequality, London: Routledge. 